Artikel Penelitian

\title{
ANALISIS TINGKAT PENGETAHUAN DAN SIKAP TENAGA KEFARMASIAN DALAM MENCEGAH OBAT RUSAK DAN KADARLUARSA DI RSUD TORA BELO
}

\author{
The Analysis Of Knowledge And Attitude Of Pharmaceutical \\ Personnel In Preventing Defective And Expired Drugs At Tora Belo \\ Hospital
}

\author{
Nurul Ambianti ${ }^{1 *}$, Muhamad Rinaldhi Tandah, Khusnul Diana , Ratu Balqis \\ ${ }^{1}$ Jurusan Farmasi, Fakultas Matematika dan Ilmu \\ Pengetahuan Alam, Universitas Tadulako, Jl Soekarno \\ Hatta No. KM. 9, Tondo, Mantikulore, Kota Palu, \\ Sulawesi Tengah 94148, Indonesia \\ *E-mail: nurul.ambianti@gmail.com
}

\begin{abstract}
Abstrak
Obat rusak dan kadaluarsa merupakan salah satu masalah yang dapat mencerminkan ketidaktepatan dan kurang baiknya manajemen pengelolaan obat di sebuah Instalasi Farmasi Rumah Sakit (IFRS). Penelitian ini dilakukan untuk mengetahui tingkat pengetahuan dan sikap tenaga kefarmasian dalam mencegah obat rusak dan kadaluarsa di Rumah Sakit Umum Daerah (RSUD) Tora Belo. Jenis penelitian ini adalah penelitian noneksperimental dengan pengambilan data secara cross sectional. Data yang digunakan adalah data primer yang diperoleh dari hasil kuesioner yang telah diisi oleh tenaga kefarmasian di RSUD Tora Belo. Analisis yang digunakan pada penelitian ini adalah analisis korelasi menggunakan uji Spearman-Rho, untuk mengetahui hubungan tingkat pengetahuan dan sikap tenaga kefarmasian dalam mencegah obat rusak dan kadaluarsa. Jumlah sampel adalah 33 orang yang diambil secara total sampling. Waktu pengambilan data penelitian selama bulan Mei-Oktober 2020. Dari hasil penelitian dapat diperoleh pengetahuan tenaga kefarmasian dalam mencegah obat rusak dan kadaluarsa dikategorikan cukup yaitu sebanyak 17 orang $(71,1 \%)$, sikap tenaga kefarmasian dalam mencegah obat rusak dan kadaluarsa dikategorikan sangat kuat yaitu sebanyak 18 orang $(85,78 \%)$, serta hasil analisis korelasi tingkat pengetahuan dan sikap tenaga kefarmasian dalam mencegah obat rusak dan kadaluarsa diperoleh nilai signifikansi sebesar 0,021 , sehingga dapat disimpulkan bahwa terdapat hubungan antara tingkat pengetahuan dan sikap tenaga kefarmasian dalam mencegah obat rusak dan kadaluarsa di RSUD Tora Belo.
\end{abstract}

Keywords: obat rusak, obat kadaluarsa, pengetahuan, sikap 


\begin{abstract}
The defective and expired drugs are one of the problems that can reflect the inaccuracy and poor of drug management in a Hospital Pharmacy Unit (HPU). This research was conducted to determine the level of knowledge and attitudes of pharmaceutical personnel in preventing defective and expired drugs at the Regional General Hospital (RGH) Tora Belo. This type of researched is a non-experimental study with cross sectional data collection. The data used are primary data obtained from the results of questionnaires that have been filled out by pharmacist at Tora Belo Hospital. The analysis used in this study is correlation analysis using the SpearmanRho test, to determine the relationship between the level of knowledge and attitudes of pharmaceutical personnel in preventing defective and expired drugs. The number of samples is 33 people taken by total sampling. Time to collect research data during May-October 2020. From the results of the study, it is known that the level of knowledge of the respondents is dominated by the sufficient category, namely 17 respondents $(71.1 \%)$, it is known that the attitude of the respondents was included in the very strong category of 18 respondents (85.78\%), and the results of the correlation analysis the relationship between the level of knowledge and attitudes of pharmaceutical personnel in preventing defective and expired drugs obtained a significance value of 0.021 . So it can be concluded there is a relation between the level of knowledge and attitude of pharmaceutical workers in preventing defective and expired drugs at Tora Belo Hospital.
\end{abstract}

Keywords: Defective Drug, Expired Drug, Knowledge, Attitude

\title{
PENDAHULUAN
}

Instalasi Farmasi Rumah Sakit (IFRS) merupakan pusat pelayanan di rumah sakit yang mana salah satu fungsinya adalah melakukan pengelolaan dan pengendalian sediaan farmasi dan perbekalan kesehatan. Sediaan farmasi yang dimaksud diantaranya obat, bahan obat, gas medis dan alat kesehatan (Rusli, 2016). Pengelolaan perbekalan farmasi atau sediaan farmasi merupakan suatu siklus dari kegiatan yang dimulai dari merencanakan hingga mengevaluasi kegiatan yang telah dilakukan antara satu kegiatan dengan kegiatan yang lain (Komar, 2010). Tidak efisiennya dan tidak lancarnya kegiatan pengelolaan perbekalan farmasi di IFRS dapat memberi dampak atau efek negatif terhadap rumah sakit, salah satunya yaitu dapat membuat pasien yang memerlukan suatu obat, namun obat tidak tersedia tersedia di IFRS di waktu tersebut menyebabkan pasien harus membeli sendiri obat ke apotek luar (Adelheid, 2018).

Obat rusak dan kadaluarsa merupakan salah satu masalah yang dapat mencerminkan ketidaktepatan dan kurang baiknya manajemen pengelolaan obat di sebuah IFRS. Penyebab obat menjadi rusak dikarenakan proses penyimpanan obat yang salah dan proses penerimaan obat yang salah (Ardiningtyas, 2019). Kerugian akibat obat rusak dan kadaluarsa dikarenakan ketidakefisienan dan ketidaklancaran pengelolaan obat. Pada penelitian Chalidyanto di Jawa Timur, diketahui bahwa metode penyimpanan obat dalam pelaksanaanya masih tergolong kurang baik (61,54\%) (Chalidyanto, 2016). Hal yang sama juga dibuktikan pada penelitian Ardiningtyas di Yogyakarta, didapatkan bahwa kerugian akibat kerusakan obat bervariasi dengan nominal tertinggi Rp.960.000,00/tahun 
dan nominal terendah Rp.15.000,00/tahun. Sedangkan untuk kerugian akibat obat kedaluarsa memliki nominal tertinggi Rp.6.482.000,00 dan nominal terendah Rp.30.000,00 (Ardiningtyas, 2019). Didapatkan juga hasil penelitian Palupiningtyas di gudang farmasi rumah sakit Mulya, bahwa persentase obat rusak dan kadaluarsa sebesar 2,2\% atau Rp.5.651.633,00 dalam satu periode (Palupiningtyas, 2014).

Berdasarkan hasil penelitian di Puskesmas Kabupaten Banyumas, didapatkan adanya hubungan antara tingkat pengetahuan pengelolaan obat tenaga kefarmasian dengan tingkat kemampuan pengelolaan obat tenaga kefarmasian. Hubungan ini diketahui bersifat searah yang artinya jika tingkat pengetahuan dalam mengelola makin tinggi maka kemampuannya dalam mengelola juga akan semakin baik (Galistiani, 2016). Berdasarkan hasil penelitian yang telah dilakukan Papia tahun 2020 di Instalasi Farmasi RSUD Tora Belo Kabupaten Sigi, diketahui masalah anggaran dan tempat penyimpanan obat kedaluarsa belum memadai. Sehingga, didapatkan hasil nilai dari obat kadaluarsa dan rusak adalah Rp.44,056,945,00 dan didapatkan jumlah item obat yang kadaluarsa dan rusak berjumlah 35 item obat, termasuk di dalamnya 2 item obat narkotik dan psikotropik (Papia, 2020). Hal inilah yang membuat peneliti tertarik untuk menganalis is hal tersebut, khususnya bagaimana tingkat pengetahuan dan sikap tenaga kefarmasian RSUD Tora Belo terhadap pencegahan obat rusak dan kadaluarsa. Oleh karena itu, penelitian ini dimaksudkan untuk mengetahui tingkat pengetahuan dan sikap tenaga kefarmasian terhadap pencegahan obat rusak dan kadaluarsa.

\section{BAHAN DAN METODE}

\section{Desain Penelitian}

Penelitian ini merupakan penelitian non-eksperimental yang menggunakan jenis penelitian analisis dengan pengambilan data secara cross sectional. Data yang digunakan adalah data primer yang diperoleh dari hasil kuesioner yang telah diisi oleh tenaga kefarmasian di RSUD Tora Belo Kabupaten Sigi. Data yang telah terkumpul dianalis is menggunakan metode analis is korelasi untuk mengetahui hubungan tingkat pengetahuan dan sikap tenaga kefarmasian dalam mencegah obat rusak dan kadaluarsa di RSUD Tora Belo.

\section{Populasi}

Populasi penelitian ini adalah seluruh tenaga kefarmasian yaitu apoteker dantenaga teknis kefarmasian yang bekerja di RSUD Tora Belo Kabupaten Sigi pada bulan Oktober 2020 yang berjumlah 33 orang. Adapun Sampel pada penelitian ini adalah seluruh tenaga kefarmasian yang bekerja di RSUD Tora Belo Kabupaten Sigi pada bulan Oktober 2020 berjumlah 33 orang. Pengambilan sampel dilakukan dengan cara total sampling yaitu teknik pengambilan sampel dimana jumlah sampel sama dengan jumlah populasi, dikarenakan jumlah populasi yang kurang dari 100 orang (Aminuddin, 2013). 


\section{Ins trumen Penelitian}

Instrumen pada penelitian ini yaitu kuisioner modifikasi dari jurnal Ardininingtyas (2019) terkait pengetahuan dan sikap pada tenaga kefarmasian dalam mencegah obat rusak dan kadaluarsa. Hasil uji validitas kuesioner pengetahuan dan sikap terhadap 33 responden dengan 12 butir pertanyaan terkait pengetahuan dan 17 butir pertanyaan terkait sikap. Ada 4 item pertanyaan terkait pengetahuan dan sikap yaitu definisi dan karateristik obat rusak dan kadaluarsa, penyebab obat rusak dan kadaluarsa, serta pencegahan obat rusak dan kadaluarsa, pecegahan obat rusak dan kadalursa. Skala instrumen yang digunakan pada penelitian ini adalah skala interval karena jawaban dari setiap kuesioner berupa tingkatan dari kategori. Hasil uji validitas dapat disajikan pada Tabel 1 dan Tabel 2 berikut:

Tabel 1. Hasil Uji Validitas Pengetahuan

\begin{tabular}{|c|c|c|c|c|}
\hline & Pertanyaan & $\begin{array}{c}\text { Nilai } \\
\text { Kolerasi }\end{array}$ & $\begin{array}{c}\text { Nilai r-tabel } \\
(a=5 \%)\end{array}$ & Keterangan \\
\hline 1. & $\begin{array}{l}\text { Obat dikatakan rusak } \\
\text { apabila } \\
\text { perubahan. }\end{array}$ & 0,372 & & Valid \\
\hline 2. & $\begin{array}{l}\text { Obat kadalursa adalah } \\
\text { obat yang masih dapat } \\
\text { dikonsumsi meskipun } \\
\text { telah } \\
\text { perubahan rasa. }\end{array}$ & 0,676 & & Valid \\
\hline 3. & $\begin{array}{l}\text { Obat kadalursa ditentukan } \\
\text { sejak obat masuk ke } \\
\text { gudang IFRS. }\end{array}$ & 0,668 & & Valid \\
\hline 4. & $\begin{array}{l}\text { Obat kadalursa adalah } \\
\text { obat yang berada di IFRS } \\
\text { dalam jangka waktu yang } \\
\text { lama. }\end{array}$ & 0,534 & & Valid \\
\hline 5. & $\begin{array}{l}\text { Kemasan obat yang } \\
\text { menggembung } \\
\text { menandakan obat telah } \\
\text { lama disimpan }\end{array}$ & 0,503 & & Valid \\
\hline 6. & $\begin{array}{l}\text { Suhu } 40^{\circ} \mathrm{C} \text { adalah suhu } \\
\text { optimal dalam } \\
\text { penyimpanan obat di } \\
\text { IFRS. }\end{array}$ & 0,670 & & Valid \\
\hline 7. & $\begin{array}{l}\text { Obat termolabil dapat } \\
\text { disimpan di lemari } \\
\text { penyimpanan bersama } \\
\text { dengan obatlainnya. }\end{array}$ & 0,490 & 0,344 & Valid \\
\hline 8. & $\begin{array}{l}\text { Rusaknya suatu obat } \\
\text { disebabkan } \\
\text { paparan dari } \\
\begin{array}{l}\text { lampu. } \\
\text { lampahaya }\end{array}\end{array}$ & 0,742 & & Valid \\
\hline & $\begin{array}{l}\text { Pembuatan formularium } \\
\text { RS disesuaikan dengan } \\
\text { resep dokter. }\end{array}$ & 0,447 & & Valid \\
\hline & $\begin{array}{l}10 \text { tahun sekali dilakukan } \\
\text { pengadaan perbekalan } \\
\text { farmasi }\end{array}$ & 0,712 & & Valid \\
\hline & $\begin{array}{ll}\text { Suppositoria } & \text { disimpan } \\
\text { bersampingan } & \text { dengan } \\
\text { sediaan tablet. } & \end{array}$ & 0,582 & & Valid \\
\hline & $\begin{array}{l}\text { Sediaan sirup disimpan di } \\
\text { lemari pendingin. }\end{array}$ & 0,676 & & Valid \\
\hline
\end{tabular}


Tabel 2. Hasil Uji Validitas Sikap

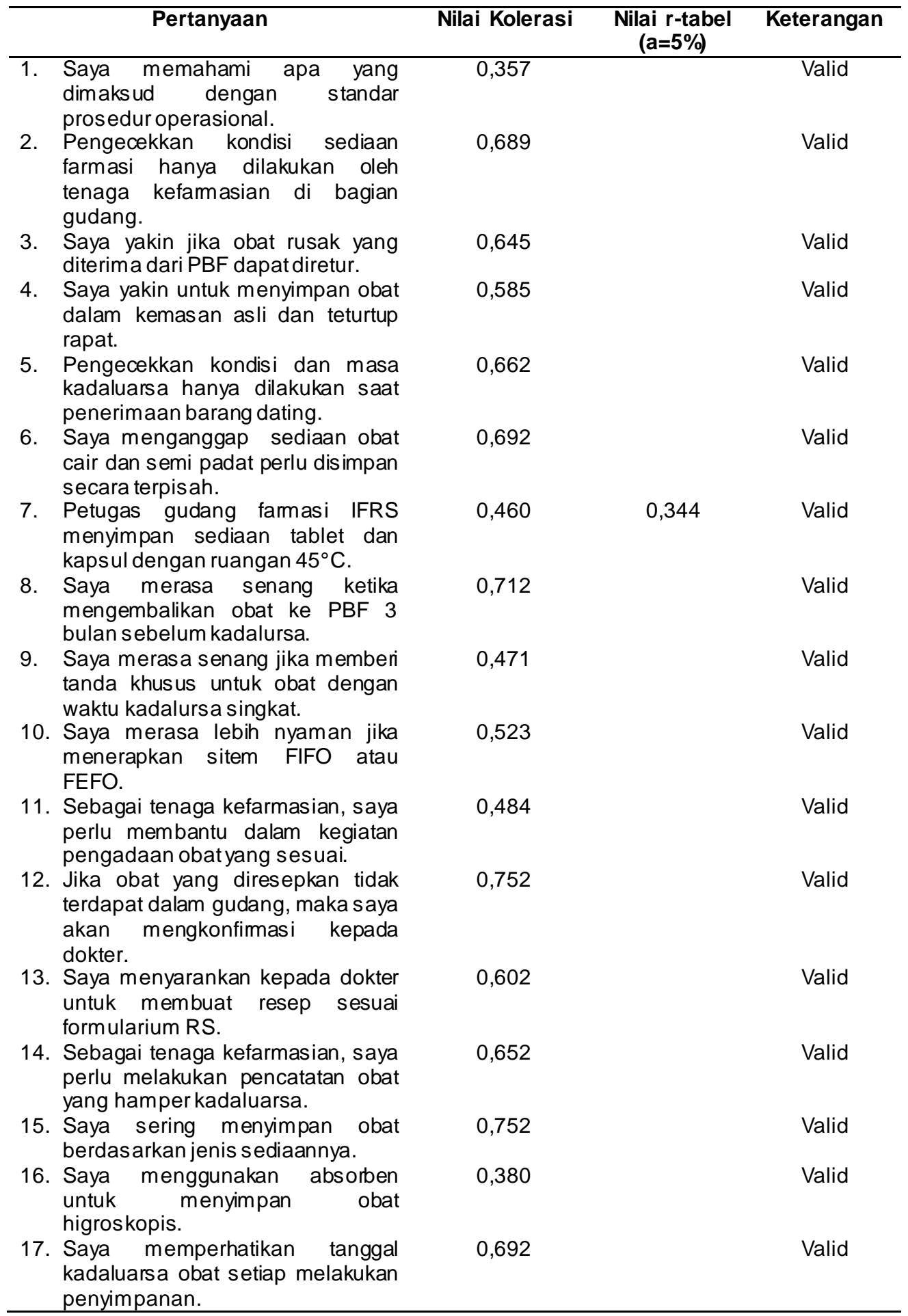

Pada uji reliabilitas pengetahuan dan sikap terhadap 33 responden didapakan hasil koef is ien alpha pengetahuan adalah 0,684 dan sikap adalah 0,808 yang berarti reliable. 


\section{Teknik Pengumpulan Data}

Pengumpulan data dilakukan melalui obeservasi untuk mendapatkan data demografi responden berupa usia, jenis kelamin, status pekerjaan, pendidikan terakhir, lama bekerja, tenaga kefarmasian, ruang bertugas dan penghasilan perbulan dan menggunakan daftar pertanyaan berupa kuisioner yang diisi langsung oleh responden serta data demografi

\section{Analisis Data}

Analisis data dalam penelitian menggunakan analisis deskriptif yaitu untuk mengetahui deksripsi dari karakteristik subjek penelitian, perhitungan tingkat pengetahuan tenaga kefarmasian dalam mencegah obat rusak dan kadaluarsa, perhitungan sikap tenaga kefarmasian dalam mencegah obat rusak dan kadaluarsa, uji normalitas memakai uji one sample kolmogorov-smirnov. Uji ini bertujuan untuk mengetahui apakah sebaran data yang dimiliki terdistribusi normal atau tidak, dan uji korelasi menggunakan analisis korelasi untuk mengetahui hubungan tingkat pengetahuan dan sikap tenaga kefarmasian dalam mencegah obat rusak dan kadaluarsa.

\section{HASIL}

\section{Karateristik Responden}

Responden dalam penelitian ini merupakan tenaga kefarmasian yang bekerja di RSUD Tora Belo, karateristik responden didapatkan dari kuisioner yang diisi oleh responden. Berikut gambaran karakteristik responden pada tabel 3

Tabel 3. Karateristik Responden

\begin{tabular}{|c|c|c|c|}
\hline \multicolumn{2}{|c|}{ Karateristik Responden } & \multirow{2}{*}{$\begin{array}{c}\begin{array}{c}\text { Jumlah } \\
(\mathrm{n}=33)\end{array} \\
15\end{array}$} & \multirow{2}{*}{$\begin{array}{c}\begin{array}{c}\text { Persentase } \\
\text { (\%) }\end{array} \\
45,5\end{array}$} \\
\hline a. Umur & $<30$ tahun & & \\
\hline & 30-40 tahun & 16 & 48,5 \\
\hline & $>40$ tahun & 2 & 6,0 \\
\hline \multirow[t]{2}{*}{ b. Jenis Kelamin } & Laki-laki & 7 & 21,2 \\
\hline & Perempuan & 26 & 78,8 \\
\hline \multirow[t]{4}{*}{ c. Pendidikan Terakhir } & Profesi Apoteker & 8 & 24,2 \\
\hline & S1 Farmasi & 5 & 15,2 \\
\hline & D3 Farmasi & 19 & 57,6 \\
\hline & Lainnya & 1 & 3,0 \\
\hline \multirow[t]{3}{*}{ d. Status Pekerjaan } & PNS & 13 & 39,4 \\
\hline & Kontrak & 18 & 54,5 \\
\hline & Lainnya & 2 & 6,1 \\
\hline \multirow[t]{3}{*}{ e. Lama Bekerja } & $<1$ tahun & 1 & 3,0 \\
\hline & 1-5 tahun & 19 & 57,6 \\
\hline & $>5$ tahun & 13 & 39,4 \\
\hline \multirow[t]{2}{*}{ f. Tenaga Kefarmasian } & Apoteker & 8 & 24,2 \\
\hline & Tenaga Teknis Kefarmasian & 25 & 75,8 \\
\hline \multirow{5}{*}{ g. Ruang Bertugas } & Instalasi Farmasi & 4 & 12,1 \\
\hline & Depo Rawat Jalan & 7 & 21,2 \\
\hline & Depo Rawat Inap & 12 & 36,4 \\
\hline & Depo IBS & 4 & 12,1 \\
\hline & Depo IGD & 6 & 18,2 \\
\hline \multirow{3}{*}{$\begin{array}{l}\text { h. Penghasilan } \\
\text { Perbulan }\end{array}$} & Rp500.000-Rp1.000.000,- & 15 & 45,5 \\
\hline & $\begin{array}{l}\text { >Rp1.000.000- } \\
\text { Rp5.000.000,-- }\end{array}$ & 17 & 51,5 \\
\hline & Lainnya & 1 & 3,0 \\
\hline
\end{tabular}


Berdasarkan tabel 4 sebanyak 16 responden $(48,5 \%)$ memiliki umur berkisar $30-40$ tahun dan 15 responden $(45,5 \%)$ memiliki usia $<30$ tahun. Hal ini dapat terjadi karena responden telah masuk dalam kategori rentang usuia produktif, yang mana pada usia produktif seseorang mampu memberikan pelayanan kefarmasian. Pada pengelompokan usia 17-25 tahun (remaja akhir), 26-35 tahun (dewasa awal), dan 36-45 tahun (dewasa akhir) merupakan kelompok yang termasuk kedalam usia produktif untuk bekerja (Kementrian Kesehatan RI, 2009). Penduduk dengan usia 15-64 tahun termasuk ke dalam usia produktif karena dianggap mampu memberikan jasa dalam pelayanan termasuk dalam pelayanan tenaga kefarmasian, sehingga usia tenaga kefarmasian didominasi dengan usia 15-64 tahun (Sukmaningrum \& Imron, 2017). Hal yang sama seperti yang disebutkan pada penelitian Satibi (2018) dan Robiyanto (2019), yaitu tenaga kefarmasian didominasi dengan rentang usia 15-64 tahun.

Responden penelitian terbanyak berjenis kelamin perempuan dengan jumlah 26 responden $(78,8 \%)$. Hal ini disebabkan, karena perempuan cenderung untuk bekerja di tempat yang melibatkan orang lain sedangkan laki-laki cenderung untuk bekerja di tempat yang menggunakan mesin. Berdasarkan penelitian Ismail (2020), diketahui bahwa faktor yang dapat menyebabkan tingginya jumlah tenaga kefarmasian berjenis kelamin perempuan di antaranya adalah pada proses perkuliahan dan pada saat pekerjaan kefarmasian diperlukan tingkat ketelitian yang tinggi, yang masyarakat berasumsi bahwa orang dengan jenis kelamin perempuan memiliki tingkat ketelitian yang tinggi dibandingkan orang dengan jenis kelamin laki- laki, dan berdasarkan faktor biologi yang dimiliki perempuan, terdapat hormon estrogen dan progesterone yang membuat perempuan bersifat feminim, yang mana sifat ini dipersepsikan lebih cocok untuk pekerjaan kefarmasian. Hasil ini seperti yang disebutkan dalam penelitian Satibi (2018), yaitu jumlah tenaga kefarmasian yang berjenis ke lamin perempuan lebih banyak dibanding tenaga kefarmasian yang berjenis kelamin laki-laki.

Berdasarkan data pendidikan terakhir yang diperoleh, responden dengan pendidikan terakhir yang mendominasi adalah D3 Farmasi dengan jumlah 19 responden $(57,6 \%)$. Jenis tenaga kefarmasian sendiri terdiri dari apoteker dan tenaga teknis kefarmasian yang dapat melakukan pekerjaan kefarmasian di rumah sakit. Banyaknya tenaga kefarmasian yang menempuh pendidikan hingga D3 Farmasi dikarenakan lulusan D3 Farmasi tergolong sebagai Tenaga Teknis Kefarmasian (TTK) yang dapat melakukan pelayanan kefarmasian seperti produksi sediaan farmasi, pendistribusian sediaan farmasi dan menjadi asisten penelitian (Kementrian Kesehatan RI, 2016). Berdasarkan Profil RSUD Tora Belo tahun 2020 diketahui bahwa RSUD Tora Belo masih termasuk dalam tipe rumah sakit ke las $\mathrm{C}$, yang mana tenaga kefarmasian yang melakukan pelayanan medik telah diatur dalam Permenkes RI tahun 2014 tentang klasifikasi dan perizinan rumah sakit yaitu tenaga kefarmasian yang melakukan pelayanan di rumah sakit umum kelas C didominasi oleh tenaga teknis kefarmasian yang jumlahnya disesuaikan dengan beban kerja pelayanan kefarmasian di rumah sakit tersebut (Beba, 2020). Sehingga, tenaga kefarmasian yang ingin mendapatkan pekerjaan dan telah memiliki pendidikan akhir D3 farmasi memiliki peluang untuk mendapatkan pekerjaan di RSUD Tora Belo. 
Berdasarkan data diperoleh status pekerjaan terbanyak adalah kontrak yang berjumlah 18 responden $(54,5 \%)$. Banyaknya tenaga kefarmasian yang masih berstatus kontrak disebabkan karena adanya kebijakan yang dikeluarkan oleh pemerintah daerah Sigi dalam pengerusan kepegawaian yaitu kepegawaian masyarakat Sigi masih akan ditata kembali untuk menghasilkan SDM yang berkualitas (Pemerintah Kabupaten Sigi, 2017). Berdasarkan kebijakan pemerintah tersebutlah masyarakat di daerah Kabupaten Sigi memiliki status pekerjaan kontrak yang lebih banyak dibandingkan dengan status pekerjaan PNS.

Lama bekerja responden didominasi 1-5 tahun dengan jumlah 19 responden $(57,6 \%)$. Penyebab banyaknya responden yang memiliki lama bekerja di RSUD Tora Belo berkisar 1-5 tahun dibandingkan lama bekerja $>5$ tahun dikarenakan RSUD Tora Belo tergolong rumah sakit baru. Sehingga, tenaga kefarmasian yang bekerja di RSUD Tora Belo di awal pengoprasian rumah sakit masihlah sedikit. Berdasarkan Beba (2020), diketahui bahwa RSUD Tora Belo didirikan pada tahun 2013 dan mulai beroperasi pada tahun 2014 hingga sekarang. Lama bekerja responden yang berkisar antara 1-5 tahun dapat mempengaruhi kemampuannya dalam melakukan pekerjaannya. Semakin lama seseorang bekerja maka kinerja atau kemampuan dalam melakukan pekerjaannya akan meningkat dikarenakan bertambahnya pengalaman yang dimiliki. Sehingga, lama bekerja tenaga kefarmasian di rumah sakit dapat mempengaruhi kemampuan tenaga kefarmasian dalam pengelolaan perbekalan farmasi. Hal ini seperti yang disebutkan dalam penelitian Hanggara (2017), bahwa tenaga teknis kefarmasian didominasi dengan masa kerja $>1$ tahun. Tetapi hasil ini tidak menunjukkan hubungan yang signifikan antara lama bekerja dengan kemampuan tenaga kefarmasian karena terdapat faktor lain yang dapat mempengaruhi kemampuan tenaga kefarmasian dalam melakukan pengelolaan perbekalan farmasi di rumah sakit (El et al., 2011).

Tenaga teknis kefarmasian menjadi responden terbanyak dengan jumlah 25 responden $(75,8 \%)$. Hal ini berhubungan dengan hasil yang didapatkan sebelumnya, yaitu pendidikan akhir responden yang didominasi dengan lulusan D3 Farmasi. Lulusan D3 Farmasi tergolong sebagai Tenaga Teknis Kefarmasian (TTK) yang dapat melakukan pelayanan kefarmasian di rumah sakit.

Ruang bekerja dengan jumlah responden terbanyak adalah Depo Rawat Inap yaitu 12 responden $(36,4 \%)$. Penyebab banyaknya responden yang bekerja di depo raat inap, dikarenakan depo rawat inap memiliki umlah pasien yang lebih banyak dibandingkan dengan ruang kerja lainnya dan tenaga kefarmasian melakukan pe layanan medik selama 24 jam sehari di depo rawat inap, sehingga depo rawat inap membutuhkan jumlah tenaga kefarmasian yang banyak dibandingkan ruang kerja lainnya dalam melaksanakan pelayanan kafarmasian. Jumlah tenaga kefarmasian dalam melakukan pelayanan medik di rumah sakit te lah diatur dalam Permenkes RI tahun 2014 tentang klasifikasi dan perizinan rumah sakit yaitu tenaga kefarmasian yang melakukan pelayanan medik atau bertugas di ruang rawat inap rumah sakit umum kelas $\mathrm{C}$ sebanyak 2 orang apoteker yang dibantu dengan minimal 4 orang tenaga teknis kefarmasian atau 4 orang apoteker yang dibantu dengan minimal 8 orang tenaga teknis kefarmasian, sedangkan untuk ruangan lainnya hanya memerlukan 1 orang apoteker sebagai koordinator dengan dibantu tenaga kefarmasian yang jumlahnya disesuaikan. 
Penghasilan perbulan responden terbanyak adalah berkisar Rp1.000.000Rp5.000.000 yaitu 17 responden (51,5\%). Hal ini seperti yang disebutkan dalam penelitian Diana (2019), bahwa imbalan per bulan tenaga kefarmasian didominasi >Rp2.000.000- Rp4.000.000. Hasil ini sesuai dengan surat edaran Pengurus Daerah Ikatan Apoteker Indonesia Sulawesi Tengah yaitu standar gaji apoteker sebesar Rp2.500.000. Faktor usia, pendidikan terakhir, lama berpraktek dan penghasilan tidak memiliki pengaruh yang signifikan terhadap kinerja seseorang dalam bekerja (Schafheutle et al., 2011).

\section{Tingkat Pengetahuan Tenaga Kefarmasian dalam Mencegah Obat Rusak dan Kadaluarsa}

Pada penelitian ini kuesioner memiliki 12 item pertanyaan dimana memuat 3 indikator yaitu definisi dan karakteristik obat rusak dan kadaluarsa, penyebab obat rusak dan kadaluarsa, dan pencegahan obat rusak dan kadaluarsa. Berikut gambaran pengetahuan tenaga kefarmasian dalam mencegah obat rusak dan kadaluarsa dapat dilihat pada tabel 4 berikut:

Tabel 4. Tingkat Pengetahuan Tenaga Kefarmasian dalam Mencegah Obat Rusak dan Kadaluarsa

\begin{tabular}{clcc}
\hline No. & $\begin{array}{c}\text { Indikator } \\
\text { Kuisioner }\end{array}$ & $\begin{array}{c}\text { Rata-rata Responden } \\
\text { Menjawab Benar } \\
(\mathbf{n}=33)(\%)\end{array}$ & $\begin{array}{c}\text { Rata-rata } \\
\text { Responden } \\
\text { Menjawab Salah } \\
(\mathbf{n}=33)(\%)\end{array}$ \\
\hline $1 . \quad \begin{array}{l}\text { Definisidan } \\
\text { karateristik obat } \\
\text { rusak dan }\end{array}$ & $30,3(92,0 \%)$ & $(8,0 \%)$ \\
kadaluarsa & & \\
2. & $\begin{array}{l}\text { Penyebab obat } \\
\text { rusakdan }\end{array}$ & 22,0 & 11,0 \\
kadalursa & $\begin{array}{l}\text { Pencegahan } \\
\text { obat rusak dan } \\
\text { kadaluarsa }\end{array}$ & 21,0 & $(33,0 \%)$ \\
& $(64,0 \%)$ & 12,0 \\
\hline
\end{tabular}

Tabel 4 menjelaskan bahwa responden memiliki pengetahuan dalam mencegah obat rusak dan kadaluarsa. Pada indikator pertama rata-rata responden yang menjawab pertanyaan dengan tepat mendominasi pengetahuan yang dimiliki responden. Hal ini dapat terjadi karena tenaga kefarmasian yang bekerja di RSUD Tora Belo telah memahami definisi dan karaktersitik obat rusak dan kadaluarsa. Pengetahuan terkait definisi dan karakteristik obat rusak dan kadaluarsa mendominasi pengetahuan yang dimiliki responden karena pengetahuan terkait definisi dan karakteristik obat rusak dan kadaluarsa merupakan dasar dari tenaga kefarmasian untuk mencegah penggunaan obat rusak dan kadaluarsa pada saat melakukan pelayanan kefarmasian di rumah sakit. Dibandingkan dengan indikator yang pertama, pada indikator kedua dan ketiga masih banyak responden yang menjawab pertanyaan dengan salah. Penyebab banyaknya responden yang masih kurang paham terkait penyebab dan pencegahan obat rusak dan kadaluarsa karena sebagian besar tenaga kefarmasian di RSUD Tora Belo dalam melakukan pekerjaan kefarmasian bukan di gudang penyimpanan perbekalan farmasi di rumah sakit, yang mana tempat bekerja dan pekerjaan seseorang dapat mempengaruhi pengetahuan yang dimilikinya. 
Pengetahuan tenaga kefarmasian di RSUD Tora Belo dalam mencegah obat rusak dan kadaluarsa didapatkan saat pendidikan dan saat melakukan pekerjaan kefarmasian di rumah sakit. Pekerjaan kefarmasian yang dilakukan responden di rumah sakit dapat meningkatkan pengetahuan terkait pengelolaan perbekalan farmasi di rumah sakit, yang mana didalamnya termasuk pengetahuan dalam mencegah obat rusak dan kadaluarsa. Hasil yang didapatkan seperti yang disebutkan dalam penelitian Galistiani (2016), yaitu tenaga kefarmasian yang bekerja di rumah sakit memiliki pengetahuan dalam pengelolaan perbekalan farmasi di rumah sakit.

Tabel 5. Distribusi Frekuensi Tingkat Pengetahuan Tenaga Kefarmasian dalam Mencegah Obat Rusak dan Kadaluarsa

\begin{tabular}{cccc}
\hline Kategori & $\begin{array}{c}\text { Rata-rata } \\
\text { Persentase skor }\end{array}$ & $\begin{array}{c}\text { Jumlah } \\
(\mathbf{n = 3 3 )}\end{array}$ & $\begin{array}{c}\text { Persentase } \\
(\%)\end{array}$ \\
\hline Baik & 83,9 & 14 & 2,4 \\
Cukup & 71,1 & 17 & 51,5 \\
Kurang & 37,5 & 2 & 6,1 \\
\hline
\end{tabular}

Berdasarkan tabel 5 diketahui bahwa tingkat pengetahuan responden didominasi dengan kategori cukup yaitu 17 responden (51,5\%), kemudian kategori baik yaitu 14 responden $(42,4 \%)$, dan masih terdapat 2 responden $(6,1 \%)$ yang masih memerlukan perhatian khusus karena termasuk dalam kategori kurang. Tingkat pengetahuan responden didominasi dengan kategori cukup, hal ini dapat diketahui dari jawaban responden pada kuisioner yang diberikan yaitu pada masing-masing indikator responden mampu menjawab pertanyaan dengan tepat sehingga pengetahuan tenaga kefarmasian di RSUD Tora Belo termasuk kategori cukup dalam hal mencegah obat rusak dan kadaluarsa.

Tingkat pengetahuan tenaga kefarmasian termasuk kategori cukup dapat disebabkan beberapa faktor, diantaranya umur, pendidikan akhir dan lama bekerja responden. Umur tenaga kefarmasian yang bekerja di RSUD Tora Belo didominasi dengan umur lebih dari 25 tahun, yang mana pada umur tersebut tenaga kefarmasian telah memiliki banyak pengalaman yang dapat mempengerahui pengetahuan yang dimilikinya. Lama bekerja adalah ukuran dari durasi waktu yang ditempuh selama bekerja seseorang untuk dapat memahami dan melaksanakan pekerjaan dengan baik. Kemampuan untuk memahami hal tersebut merujuk pada definisi pengetahuan, sehingga erat hubungannya antara lama bekerja dengan tingkat pengetahuan seseorang (Riyadi, 2018). Lama bekerja tenaga kefarmasian di RSUD Tora Belo didominasi dengan 1-5 tahun, akibatnya tenaga kefarmasian memiliki pengetahuan terkait pekerjaan kefarmasian di rumah sakit termasuk pengetahuan dalam mencegah obat rusak dan kadaluarsa. Adanya pengaruh faktor umur dan lama bekerja menyebabkan peningkatan pengetahuan yang dimiliki responden, dari pengetahuan yang kurang hingga memiliki pengetahuan yang cukup.. Hasil ini seperti yang disebutkan pada penelitian Galistiani (2016), yaitu pengalaman yang kurang serta lama bekerja merupakan faktor yang menyebabkan tingkat pengetahuan tenaga kefarmasian menjadi kurang.

Pengetahuan yang dimiliki responden dipengaruhi oleh pendidikan akhir responden yang didominasi D3 Farmasi. Pendidikan yang telah ditempuh dapat mempengaruhi banyak dan luasnya pengetahuan responden. Hal ini disebabkan karena adanya proses yang dilakukan seseorang untuk 
mengalami perubahan untuk memahami suatu informasi. Informasi yang terkait suatu pembelajaran akan menambah pengetahuan seseorang mengenai pelajaran tersebut. Pengetahuan yang telah didapatkan tersebut yang terus diingat dan dikembangkan hingga responden melakukan pekerjaan kefarmasian dirumah rumah sakit, sehing ga tenaga kefarmasian yang bekerja di RSUD Tora Belo memiliki pengetahuan yang cukup dalam mencegah obat rusak dan kadaluarsa. Hasil ini seperti yang disebutkan dalam penelitian Bagaskoro (2019), yaitu pendidikan yang tinggi dan lama bekerja responden yang didominasi 1- 5 tahun dapat membuat tenaga kefarmasian memiliki informasi yang banyak dari pekerjaan yang dilakukan sehari-hari terkait pengelolaan perbekalan farmasi di rumah sakit.

\section{Sikap Tenaga Kefarmasian dalam Mencegah Obat Rusak dan Kadaluarsa}

Berikut gambaran sikap tenaga kefarmasian dalam mencegah obat rusak dan kadaluarsa dapat dilihat pada tabel 6 :

Tabel 6. Sikap Tenaga Kefarmasian dalam Mencegah Obat Rusak dan Kadaluarsa

\begin{tabular}{|c|c|c|c|c|c|}
\hline \multirow[t]{2}{*}{ No. } & \multirow{2}{*}{$\begin{array}{l}\text { Indikator } \\
\text { Kuisioner }\end{array}$} & \multicolumn{4}{|c|}{ Rata-rata responden $(n=33)$} \\
\hline & & SS & $\mathbf{S}$ & TS & STS \\
\hline 1. & $\begin{array}{c}\text { Kognitif } \\
\text { (Perseptual) }\end{array}$ & $\begin{array}{c}9,3 \\
(28,2 \%)\end{array}$ & $\begin{array}{c}19,4 \\
(58,8 \%)\end{array}$ & $\begin{array}{c}2,1 \\
(6,4 \%)\end{array}$ & $\begin{array}{c}2,1 \\
(6,4 \%)\end{array}$ \\
\hline 2. & $\begin{array}{c}\text { Afektif } \\
\text { (Perasaan) }\end{array}$ & $\begin{array}{c}18,0 \\
(54,5 \%)\end{array}$ & $\begin{array}{c}13,0 \\
(39,4 \%)\end{array}$ & $\begin{array}{c}1,7 \\
(5,1 \%)\end{array}$ & $\begin{array}{c}0,3 \\
(1,0 \%)\end{array}$ \\
\hline 3. & $\begin{array}{c}\text { Konatif } \\
\text { (Perilaku) }\end{array}$ & $\begin{array}{c}10,7 \\
(32, \%)\end{array}$ & $\begin{array}{c}19,6 \\
(59,4 \%)\end{array}$ & $\begin{array}{c}2,7 \\
(8,2 \%)\end{array}$ & 0 \\
\hline
\end{tabular}

Ket : SS (Sangat Setuju), S (Setuju), TS (Tidak setuju), STS (Sangat Tidak Setuju)

Berdasarkan tabel 6 diketahui jawaban responden pada kuisioner sikap dengan indikator kognitif (perseptual) didominasi dengan rata-rata jawaban responden setuju yaitu 19,4 (58,8\%). Pada indikator tersebut menunjukkan bahwa tenaga kefarmasian di RSUD Tora Belo memiliki opini menyangkut sikap dalam mencegah obat rusak dan kadaluarsa. Hal ini dapat terjadi karena responden memiliki kepercayaan yang mempengaruhinya dalam berperilaku. Indikator afektif (perasaan) didominasi dengan rata-rata jawaban reponden sangat setuju yaitu 18,0 (54,5\%), yang menunjukkan bahwa tenaga kefarmasian di RSUD Tora Belo memiliki perasaan dalam mencegah obat rusak dan kadaluarsa. Hal ini dapat terjadi karena pada indikator afektif responden lebih menggunakan perasaan atau emosi dalam membentuk sikap, sehingga tidak mudah untuk mengubah sikap seseorang. Pada indikator konatif (perilaku) didominasi dengan rata-rata jawaban reponden setuju yaitu 19,6 (59,4\%) yang menunjukkan bahwa tenaga kefarmasian di RSUD Tora Belo memiliki tendensi atau kecenderungan dalam berperilaku terkait sikap dalam mencegah obat rusak dan kadaluarsa.

Berdasarkan hasil yang telah dipaparkan di atas, diketahui bahwa tenaga kefarmasian di RSUD Tora Belo memiliki sikap yang harus dimiliki seorang tenaga kefarmasian dalam mencegah obat rusak dan kadaluarsa di rumah sakit. Penyebab responden mampu menjawab pertanyaan dari kuisioner yang diberikan karena responden memiliki pengetahuan yang cukup dalam mencegah obat rusak dan kadaluarsa. Hal ini didukung pada penelitian 
Deviani (2017), bahwa pengetahuan tenaga kefarmasian yang baik dapat mendukung sikap tenaga kefarmasian yang baik juga.

Tabel 7. Distribusi Frekuensi Sikap Tenaga Kefarmasian dalam Mencegah Obat Rusak dan Kadaluarsa

\begin{tabular}{cccc}
\hline Kategori & $\begin{array}{c}\text { Rata-rata persentase } \\
\text { skor }\end{array}$ & $\begin{array}{c}\text { Jumlah } \\
(\mathbf{n}=\mathbf{3 3})\end{array}$ & $\begin{array}{c}\text { Persentase } \\
(\%)\end{array}$ \\
\hline Sangat Lemah & 0 & 0 & 0,0 \\
Lemah & 0 & 0 & 0,0 \\
Cukup & 0 & 0 & 0,0 \\
Kuat & 75,0 & 15 & 45,0 \\
Sangat Kuat & 85,78 & 18 & 55,0 \\
\hline
\end{tabular}

Pada tabel 7 diketahui bahwa sikap responden termasuk dalam kategori sangat kuat sebanyak 18 responden $(55,0 \%)$ dan kategori kuat sebanyak 15 responden $(45,0 \%)$. Perbedaan antara kategori sangat kuat dan kuat terletak pada persentase skor dari kuisioner yang telah diisi oleh responden. Sikap sangat kuat dan kuat dapat diartikan bahwa responden memiliki keyakinan yang sangat kuat yang membuatnya bersedia untuk memberikan respon terhadap suatu objek yang dirasakan (Sofiyana, 2013).

Hasil yang didapatkan telah sesuai karena responden memiliki tingkat pengetahuan yang termasuk dalam kategori baik, sehingga hal tersebut dapat menunjang sikap responden yang sangat kuat dalam mencegah obat rusak dan kadaluarsa. Selain dari pengetahuan responden yang baik, sikap tenaga kefarmasian yang sangat kuat dapat diakibatkan karena lama bekerja tenaga kefarmasian lebih dari 5 tahun lebih banyak dibandingkan lama bekerja tenaga kefarmasian kurang dari 5 tahun. Tenaga kefarmasian yang bekerja lama di RSUD Tora belo dapat menimbulkan sikap yang sangat kuat karena salah satu faktor yang dapat mempengaruhi sikap seseorang adalah adanya latihan dan pengawasan yang dilakukan dari hari kehari (Sudiarta \& Wirawan, 2020). Sehingga pekerjaan yang dilakukan setiap hari oleh tenaga kefarmasian di RSUD Tora Belo memberikan sikap yang sangat kuat dalam mencegah obat rusak dan kadaluarsa.

\section{Hubungan Tingkat Pengetahuan dan Sikap Tenaga Kefarmasian dalam Mencegah Obat Rusak dan Kadaluarsa}

Hubungan tingkat pengetahuan dan sikap tenaga kefarmasian dalam mencegah obat rusak dan kadaluarsa dapat diketahui dengan metode analis is korelasi regresi non parametrik. Metode ini digunakan karena data yang diperoleh terdistribusi tidak normal. Hal ini dapat diketahui pada hasil uji normalitas data didapatkan nilai signifikansi pengetahuan dan sikap berturutturut sebesar 0,000 dan 0,004 atau <0,05, sehingga disimpulkan bahwa data terdistribusi tidak normal. Pada pengujian secara statistik menggunakan uji Spearman-Rho.

Tabel 8. Hasil Analisis Korelasi

\begin{tabular}{cccc}
\hline Kategori & $\mathbf{N}$ & Korelasi & Sig. (2-tailed) \\
\hline $\begin{array}{c}\text { Pengetahuan } \\
\text { Sikap }\end{array}$ & 33 & $0,399^{*}$ & 0,021 \\
\hline
\end{tabular}

Berdasarkan tabel 8 diketahui bahwa hasil analis is korelasi hubungan tingkat pengetahuan dan sikap tenaga kefarmasian dalam mencegah obat rusak dan 
kadaluarsa memiliki korelasi atau terdapat hubungan. Hal ini dapat diketahui karena nilai Sig. (2- tailed) didapatkan nilai 0,021. Terdapat hubungan antara tingkat pengetahuan dan sikap tenaga kefarmasian dalam mencegah obat rusak dan kadaluarsa karena responden memiliki pengetahuan yang cukup yang dapat mempengaruhi sikap tenaga kefarmasian dalam mencegah obat rusak dan kadaluarsa. Pengetahuan yang dimiliki seseorang merupakan awal atau pemicu seseorang untuk menunjukkan sikap termasuk sikap dalam mencegah obat rusak dan kadaluarsa. Hasil ini seperti yang disebutkan pada penelitian Galistiani (2016), bahwa terdapat hubungan dengan kekuatan cukup antara tingkat pengetahuan dan sikap tenaga kefarmasian dalam melakukan pengelolaan perbekalan farmasi. Penelitian Aziz (2018) juga menunjukkan bahwa sebanyak 30 responden (75\%) petugas fasilitas kesehatan sudah memiliki pengetahuan tentang pengelolaan limbah obat yang tinggi. Tingginya pengetahuan petugas pada bagian farmasi di fasilitas kesehatan disebabkan karena petugas sudah mengetahui jenisjenis limbah obat yang dihasilkan oleh unit pelayanan farmasi dan tahapan pengelolaan limbah obat kadaluarsa. Faktor lain yang berhubungan dengan tingkat pengetahuan adalah adanya Standar Operasional Prosedur (SOP) pengelolaan obat kadaluarsa dan adanya pelatihan, dimana hal ini akan sangat menambah pengetahuan dan kesadaran petugas farmasi di fasilitas kesehatan untuk mengelola limbah obat dengan baik dan benar.

\section{SIMPULAN}

Terdapat hubungan dengan kekuatan cukup dan searah pada tingkat pengetahuan dan sikap tenaga kefarmasian dalam mencegah obat rusak dan kadaluarsa di RSUD Tora Belo.

\section{SARAN}

Diharapkan pihak Instalasi Farmasi RSUD Tora Belo Sigi dapat mempertahankan dan meningkatkan pengetahuan dan sikap tenaga kefarmasian dalam mencegah obat rusak dan kadaluarsa. Serta dilakukan penelitian lebih lanjut mengenai faktor-faktor penyebab adanya obat rusak dan kadaluarsa di RSUD Tora Belo Sigi.

\section{REFERENSI}

Adelheid, 2018, Manajemen Pengelolaan Obat Terhadap Ketersediaan Obat Di Instalasi Farmasi Rumah Sakit Umum Daerah Kudungga Sangatta Kabupaten Kutai Timur. UNHAS.

Aminuddin, A. K., 2013, Gambaran Pengetahuan Remaja tentang Pornografi pada Siswa Kelas VIII Di SMPN 5 Lembang. Universitas Pendidikan Indonesia.

Ardiningtyas, B. S., 2019, Gambaran Penyebab dan Kerugian karena Obat Rusak dan Kedaluarsa. UGM.

Aziz, F.F.A., 2018, Evaluasi Pengelolaan Limbah Obat Di Fasilitas Kesehatan Dasar Di Kota Yogy akarta. Skripsi. Fakultas Teknik Sipil dan Perencanaan. Universitas Islam Indonesia, 45-46.

Bagaskoro., 2019 , Pengantar Teknologi Informatikan dan Komunikasi Data. Deepublish.

Beba, G. R. F.,2020, Profil RSUD Tora Belo. RSUD Tora Belo.

Chalidyanto, S. H., 2016, Pengelolaan Sediaan Obat pada Logistik Farmasi Rumah Sakit Umum Tipe B di Jawa Timur. Jurnal Administrasi Kesehatan Indonesia, 4(2):136-145.

Deviani, A. M., 2017, Pengetahuan dan Sikap Tenaga Kefarmasian Tentang Obat yang tidak boleh Digerus dala Resep Racikan di Apotek Wilayah Seberang Ilir Kota Palembang. Kementrian Kesehatan RI.

Diana, K., Tandah, M. R., Basuki, M, 2019, Pelaksanaan Standar Pelay anan Kefarmasian di 
Apotek Kota Palu. As-Syifaa Jurnal Farmasi, 11(1):45-54.

Galistiani, A. F., 2016, Hubungan Tingkat Pengetahuan Pengelolaan Obat terhadap Pengelolaan Obat di Puskesmas, Jurnal Manajemen Dan Pelayanan Farmasi, 6(4):303311.

Hanggara, S. L., Gibran, N. C., Kusuma, A. M., \& Galistiani, G. F., 2017, Pengaruh Keberadaan Apoteker terhadap Mutu Pelayanan Kefarmasian di Puskesmas Wilayah Kabupaten Banyumas. Jurnal Kefarmasian Indonesia, 7(1).

Ismail, A.,2020, Gambaran Karakteristik Mahasiswa dan Alumni Farmasi FKIK UIN ALAUDDIN MAKASSAR: Sebuah Tinjauan Berbasis Gender. Sipakalebbi, 4 (1).

Kementrian Kesehatan.RI., 2009, Profil Kesehatan Indonesia. Kementrian Kesehatan RI.

Kementrian Kesehatan.RI., 2016, Kurikulum Inti Pendidikan Diploma III Farmasi. Kementrian Kesehatan RI.

Komar, Z., Wurjati, R., Masrul, Istoqamah, S. N., Fachim, R., Astuti, F. B., 2010, Pedoman Pengelolaan Perbekalan Farmasi di Rumah Sakit. KEMENKES RI.

Palupiningtyas, R., 2014, Analisis Sistem Penyimpanan Obat di Gudang Farmasi Rumah Sakit Muly a Tangerang Tahun 2014. Universitas Islam Negeri Sy arif Hiday atullah.

Papia, F. Y., 2020, Analisis Proses Pendistribusian dan Pemusnahan Obat pada Instalasi Farmasi RSUD Tora Belo Kabupaten SIGI. Universitas Tadulako.

Pemerintah Kabupaten Sigi, 2017, Rencana Kerja Pemerintah Daerah (RKPD) Kabupaten Sigi Tahun Anggaran 2018. Bupati Sigi.

Purwanto, 2019, Analisis Korelasi dan Regresi Linier dengan SPSS 21 (Panduan Praktis untuk Penelitian Ekonomi Syariah). StaiaPress.

Riy adi, S., 2018, Faktor Peningkatan Kinerja melalui Job Stress. Zifatama Jawara.

Robiyanto, Nurmainah, \& Aspian, K., 2019, Keberadaan Tenaga Apoteker dan Evaluasi Pelaksanaan Pelay anan Kefarmasian di Puskesmas Wilay ah Kota Pontianak. Jurnal Sains Farmasi Dan Klinik, 6(12), 121-128.

Rusli. (2016). Farmasi Rumah Sakit dan Klinik. Kementrian Republik Indonesia.

Satibi, Daulay, E. H., Oviani, G. A., Erlianti, K., Fudholi, A., \& Puspandari, D. A. (2018). Analisis Kinerja Apoteker dan Faktor y ang Mempengaruhi pada Era Jamin an Kesehatan Nasional di Puskesmas. JMPF, 8(1).

Schafheutle, E.I., Seston, E.M., Hassel, K., 2011, Factors Influencing Phar:macist Performance: A Review of The Peer- Reviewed Literature. Health Policy (New York), 102(2-3):178-192

Sofiyana, D. D., 2013, Perbedaan Pengetahuan, Sikap dan Perilaku Ibu Sebelum dan Setelah Konseling Gizi pada Balita Gizi Buruk. Journal of Nutrition College, 142.

Sudiarta, I. N., Wirawan, P. E., 2020, Sikap Dasar Profesi Perhotelan. Pelawa Sari.

Sukmaningrum, A., Imron, A., 2017, Memanfaatkan Usia Produktif dengan Usaha Kreatif Industri Pembuatan Kaos pada Remaja di Gresik. Paradigma, 5(3).

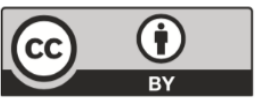

Commons Lisensi penggunaan, berbagi, adaptasi, distribusi, dan reproduksi dalam media atau format apa pun, selama Anda memberikan kredit yang sesuai kepada penulis asli dan sumbernya, memberikan tautan ke lisensi Creative Commons, dan menerangkan jika perubahan telah dilakukan. Gambar atau materi pihak ketiga lainnya dalam artikel ini termasuk dalam lisensi Creative Commons artikel, kecuali dinyatakan sebaliknya dalam batas kredit untuk materi tersebut. Jika materi tidak termasuk dalam lisensi Creative Commons artikel dan penggunaan yang Anda maksudkan tidak diizinkan oleh peraturan perundang-undangan atau melebihi penggunaan yang diizinkan, Anda harus mendapatkan izin langsung dari pemegang hak cipta. Untuk melihat salinan lisensi ini, kunjungi https://creativecommons.org/licenses/by/4.0/deed.id. 